\title{
Impact indicators of educational innovations based on active methodologies
}

\author{
Ángel Fidalgo-Blanco \\ Geological and Mining \\ Engineering \\ Technical University of Madrid \\ Madrid Spain \\ angel.fidalgo@upm.es
}

\author{
Maria Luisa Sein-Echaluce \\ Applied Mathematics \\ University of Zaragoza \\ Zaragoza Spain \\ mlsein@unizar.es
}

\author{
Francisco J. García-Peñalvo \\ Research Institute for Educational \\ Sciences, Computer Science \\ Department \\ University of Salamanca \\ Salamanca Spain \\ fgarcia@usal.es
}

\begin{abstract}
"Think global, act locally" is one of the phrases that define the idea of any innovation. It denotes that the impact must be global and contribute to the advancement of knowledge in a specific sector, for example. The innovation applied in the classroom is known as "teaching educational innovation" and thinking in global is complicated because innovation is carried out in a specific subject. Specific contexts have needs and conditions that difficult the transference outside the subject itself. This work provides a method to consider any teaching educational innovation in global terms, even before knowing the specific innovation method to apply. In this way, transferability would be enhanced and the global impact on the change of the educational model would be improved. For this purpose, a study has been carried out with more than 85 professors from different universities. The objective of the study is to show that they have a common vision on the indicators to measure the leaning impact when they apply teaching educational innovation in their own subjects.
\end{abstract}

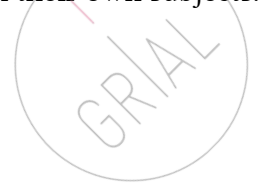

\section{KEYWORDS}

Educational innovation, active methodologies impact indicators, passive students.

\section{Introduction}

The active methodologies are based on getting students to participate actively in their learning process [15] and this aspect is intended to be enhanced through educational innovation methods such as: Flip Teaching [7], Project Based Learning [4], Gamification[20], Service Learning [21] Learning Ecosystems[24], Adaptive Learning[19], Cooperative Work[15], Learning Based on Challenges[10] and Adaptive Augmented Reality [14], among others.

In previous research work teachers indicate, as the main indicator of any educational innovation impact, that students participate actively in the learning process [13]

But this concern for active learning is one of the key aspects in the change in Higher Education in Europe[26]. It is not surprising that so many methods of educational innovation seek to enhance active learning, since active methodologies are the basis of learning models such as "Learn by Doing" by [5, 6], who proves that this active method incorporates more cognitive abilities than just listening. This is also indicated by Bloom to classify the impact of certain cognitive abilities on the learning process [2]. Kolb also says that active and continuous participation are the basis for its recognized learning cycle [18].

Other authors have described general indicators that could be used to identify when active learning occurs. Indicators such as the creation of knowledge from an existing one [22], social interaction [25] and interaction with the environment [1].

On the other hand, there are authors who have indicated the processes in which active learning occurs. Processes such as the creation and evaluation of knowledge [2], action-reflection [3] and other activities such as: cooperative work, participation in problem solving, discussion in groups and competitions $[16,17]$

But nevertheless, getting students to actively participate is complicated, mainly because our educational model leads to an inactive habit of students and teachers [9] 
Thus, in order to implement active models, it is not enough to introduce active methodologies, and an extra effort is involved to broke that inactive habit of students and teachers [12].

One of the main objectives of educational innovation is to improve the current educational model through change actions[23]. The modality of educational innovation that is applied in the classroom is called "teaching educational innovation", or simply "teaching innovation" [8] and, in that case, innovation is carried out locally, in the field of the subject.

On the other hand, the teaching innovation projects are local and are applied in the context of each subject, so it is very difficult to transfer good practices between different subjects. This causes numerous repetitions of innovation experiences, slow progress to obtain global achievements. Consequently, the improvement of the educational model, main objective of any innovation process, is slowed down.

One way to improve both, the impact on the educational model and the overall progress of the educational innovation, is based on achieving an effective mechanism of transfer between the teachers who apply educational innovation.

For this, it would be important to have indicators applicable in any subject and independent of the educational innovation method applied to improve the active participation of students. High transfer of knowledge between subjects would be achieved by those global indicators would allow to apply the phrase "think global, act locally". Although an experience of educational innovation is carried out in a local context (a specific subject), the impact can affect a global context (in the educational model) if the numerous and varied experiences of teachers serve to increase effectiveness. global.

The objective of this work is to obtain indicators that allow defining: the characteristics of active and passive students, the negative impact that occurs in the context of learning and the measurable indicators, considered as a reference to know if any experience of educational educational innovation based on active methodologies will succeed.

\section{Model}

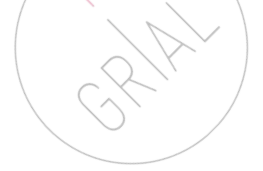

The considered model begins with the application of phase 1 of the Method for the Application of Educational Innovation[9]

The first phase of MAIN is based on obtaining indicators that serve teachers to verify the effectiveness of educational innovation through the procuded impact. Namely, measurable indicators to contrast the impact of educational innovation in the subject where it will be applied[11].

The phase 1 includes 3 previous steps to obtain the mentioned measurable indicators:

- Identify the Root Problem. The root problem must be solved or improved with the proposed innovation must be identified and it is the first step to be performed. The root problem is a situation that generally occurs in any university classroom and is caused by the educational model, rather than by students or teachers themselves. A root problem causes other common problems in the classroom, and several root problems can cause the same problem.
- Identify the characteristics of the students in which the root problem is presented. It is the second step and students who present the root problem must be identified. It is not about pointing people, but looking for evidence that allows us to recognize that this root problem is in our classroom. This step is similar to the identification of the target audience of an innovation project. Being a root problem, the identified students are usually affected to a greater or lesser extent, for this reason the target audience is all students receiving the innovation.

- Identify the learning problems that students have affected by the root problem. Root problems always have a negative impact on learning. Or, at least, to achieve a type of learning according to the today's society demands. This step tries to identify which aspects, related to learning, are more expensive to get for students affected by the root problem. Thus, it is about working to identify consequences more than characteristics.

Figure 1 shows the steps that phase 1 of the MAIN method carries with it and the relationship between those steps. As well as its relationship with measurable indicators that allow, teachers and the scientific community, to verify that educational innovation has worked.

Associating a root problem with the innovation, that teachers want to make, is simple since most innovations work with a few root problems. For example, the student's passive habit, the cost and difficulty of personalized attention to each student and the continuous evaluation by evidence.

It is important to identify the root problem and its causes in order to solve or improve it by achieving with innovation. If the causes of a problem are not known, it can never be solved and, in addition, there are problems that may be due to various causes.

For example, the lack of motivation may come from the passive habit itself, but it may also be due to the behavior of the teaching staff, the lack of prior knowledge of the student, or because they are not interested in the subject.

Once the root problem is identified and even if the teachers are not expert on it, they will be able to identify the characteristics of a student with that root problem.

From the identification of these "symptoms" of the target student, it is extremely simple to identify problems in learning (that is, the learning goals that may not be achieved if no action is taken).

Finally, the measurable indicators can be obtained, on the one hand, from the characteristics presented by the students who have the root problem. For example, if one characteristic is that they do not make the proposed works that are not punishable, a measurable indicator of impact would be the number of presentations of the proposed works and, if that number increases considerably, it means that the innovation has been successful.

On the other hand, you can also identify the measurable indicators from the consequences of learning. For example, if a consequence is that target students do not attend non-compulsory classes, the number of class attendances would be an indicator.

Phase 1 of the MAIN method is always done before choosing the method of educational innovation to be applied. In this way, 
the methods tools, associated with the innovation itself, become independent.

\section{Context}

This work has been carried out with the contribution of university professors participating in training courses on the MAIN method and in workshops for the promotion of active learning, They have been carried out during the years 2018 and 2019 in the following institutions and events:

- Course UZ- University of Zaragoza (public university)

- Course USJ- University San Jorge (private university).

- Course USAL- University of Salamanca (public university).

- Course UVIGO- University of Vigo (public university).

- Course MMCo- Conference MoodleMoot Colombia 2019. Universities in Colombia, Ecuador, Chile, Méjico, etc. (private and public universities).

In all groups we worked with the root problem "passive habit of students". Each course had a space in the Moodle platform (Moodle, 2019) and the participation of teachers (students of the courses) in three forums, has allowed to obtain the results presented in the following section of this work. A forum was implemented for each measurement:

- Forum 1. To provide the characteristics of students who present a passive habit.

- Forum 2. To contribute the consequences in the learning process of a passive student.

- Forum 3. Measurable indicators to verify the impact of the educational innovation to be carried out to solve the root problem (students' passive habit)

The participation of teachers of each university. by forum, is shown in table 1 . The last column includes the total responses in each forum.

Table 1. Participants in each forum

\begin{tabular}{|l|l|l|l|l|l|l|}
\hline & UZ & USAL & UVIGO & USJ & MMCo & Total \\
\hline Forum 1 & 27 & 15 & 15 & 13 & 19 & 89 \\
\hline Forum 2 & 27 & 13 & 15 & 14 & 19 & 88 \\
\hline Forum 3 & 27 & 14 & 14 & 14 & 19 & 88 \\
\hline
\end{tabular}

Although each column represents the same course, there are not the same participants in each forum, due to some temporary absence during the activities.

The Moodle forums used in each course were configured to show the answers once each participant had sent the own answer. The responses gave rise to a subsequent debate.

Likewise, the teachers participating in each event were advised not to relate exclusively the information requested in the forums to the final grades obtained by the students of their subject. Although the expected results of the innovation are usually related to the learning outcomes, the idea was to encourage more creativity and flexibility by teachers when providing the requested information.

\section{Results}

In the entire study the participants of the courses have sent 265 messages, answering each question posted in each forum. In turn, each message may contain one or more answers to the question posed in the forum. The total answers have been 683 , this means that, on average, 2.58 answers have been provided in each message.

For each university, the number of unique answers (those that are different) is shown in Table 2 (total: 683 answers and 282 unique answers).

Table 2. Number of answers and unique answers

\begin{tabular}{|l|r|r|r|r|r|}
\hline & UZ & UVIGO & \multicolumn{1}{l|}{ USJ } & \multicolumn{1}{l|}{ USAL } & \multicolumn{1}{|c|}{ MMCo } \\
\hline Answers & 160 & 131 & 125 & 118 & 149 \\
\hline $\begin{array}{l}\text { Different answers } \\
\text { in each course }\end{array}$ & 58 & 54 & 56 & 55 & 59 \\
\hline
\end{tabular}

From column 2 to 6 they represent the unique messages contributed in each session, which, as can be seen, are very similar, although the number of messages is different. People who participated in each session have contributed 1.06 answers on average.

Counting the total of different answers made throughout the study, you have given a total of 93, with a progression shown in table 3. For example, UVIGO includes 22 answers which are differnte from the 58 given by UZ, USJ includes 100 answers different to the 80 answers given by UZ and UVIGO, and so on..

Table 3. Progression of unique answers

\begin{tabular}{|l|c|c|c|c|c|c|}
\hline & UZ & UVIGO & USJ & USAL & MMCo & TOTAL \\
\hline $\begin{array}{l}\text { Unique } \\
\text { answers }\end{array}$ & 58 & 22 & 10 & 3 & 0 & 93 \\
\hline
\end{tabular}

The $86 \%$ of the total unique answers were provided in the first two institutions studied. Likewise, if the unique answers are counted against the total of the answers obtained in the study, it is obtained that $13.61 \%$ of the interventions have generated $100 \%$ of the unique answers.

The answers are provided by the teaching staff in different places and dates and each course is organized in a Moodle space to which only participants in it have access. Therefore, in each course the participants have not seen the answers provided by the rest of the courses. In the same course they watch the answers of the rest of participants, only when they have answered. Under these conditions there is a high coincidence in unique answers, 
specifically $87.39 \%$ of the answers reinforce $13.61 \%$ of the unique answers.

The characteristics of the target group, its impact in the learning process and the indicators of the learning improvement after applying the innovation, are obtained from de analysis of the unique answers to the forums in the five courses, and it is shown below.

\section{Analysis of the unique answers}

To simplify and focus on the most relevant answers, those that are considered similar have been associated. Once they have been grouped, they have been sorted taking into account the type, the number of universities and the number of repetitions (number of times that the same answer appears). The two most important, of each type, are presented. The classification of answers is the following:

- $\quad$ AT. Attitude.

- PA. Proposed activities.

- $\quad$ LK. Learning / Knowledge

- $\quad$ CR. Attitude in the classroom.

- TA. Tutorial action.

In order to organize the answers for each forum, two numbers are added, the first one for the forum and the second for the group of similar answer inside the same classification (for example, AT12 the second answer of the gropu AT (attitude) in forum 1).

To select an answer as valid, at least there must be a $60 \%$ match of the courses. In this process, a maximum of two unique answers are selected, organized by the number of matching courses and the number of idential answers provided.

Forum 1. Characteristics of passive students

Table 4 shows the main characteristics that define passive students according to the study participants. The first column "Type" indicates the type of answer, the second column "Answer" describes the answer (if it is generic, more details are given below the table), the third column "Repetition" indicates the number of times that the answer is given. And the last column "Universities" includes the number of courses where that answer has been given. Remember the meaning of the types, AT- Attitude. PA- Proposed activities. CR-Attitude in the classroom.
Table 4. Classification of answers in Forum 1

\begin{tabular}{|c|c|c|c|}
\hline Type & Answer (Student ...) & Repetition & Courses \\
\hline AT1 -1 & $\begin{array}{l}\text {... shows non verbal } \\
\text { language }\end{array}$ & 35 & 5 \\
\hline AT1-2 & $\begin{array}{l}\ldots \text { is isolated, does not } \\
\text { interact and shows no } \\
\text { interest }\end{array}$ & 9 & 4 \\
\hline PA1-1 & $\begin{array}{l}\ldots \text { does not participate } \\
\text { in proposed activities }\end{array}$ & 28 & 5 \\
\hline PA1-2 & $\begin{array}{l}\text {... has negative attitude, } \\
\text { protests }\end{array}$ & 5 & 4 \\
\hline CR1-1 & $\begin{array}{l}\text {... does not participate } \\
\text { in class }\end{array}$ & 82 & 5 \\
\hline CR1-2 & ... does not take notes & 9 & 4 \\
\hline
\end{tabular}

Attitude

- AT1-1. Nonverbal language. This answer groups all attitudes of the student that betrays their passivity, even if he/she says nothing, such as: look at the mobile, ignores what is said in class, mechanical assent, does not look at the teaching staff, lost look, sits in the last row, etc. $100 \%$ match of participating courses have 35 similar responses.

AT1-2. Non participatory. An specific participant defined this characteristic as a "living statue", since student is able to isolate himself from what happens in class, without interacting or showing interest in anything. Matching $80 \%$ of universities with 9 similar responses.

\section{Proposed activities}

These are activities that teachers propose to improve learning and they do not have an associated score for the final grade.

- PA1-1. Student does not participate in those activities, specially if they are not mandatory. There is a $100 \%$ coincidence of courses with 28 answers.

- PA1-2. Negative attitude. Student argues for the proposed activities. There is a coincidence of $80 \%$ of courses with 5 similar answers.

Attitude in the classroom

- CR1-1. Non-participatory attitude in the classroom. When student: does not answer to of any kind of questions made by teachers (although they know the answer), does not raise questions, does not participate in debates, does bot ask for clarifications, does not appear on the blackboard/whiteboard. There is a $100 \%$ coincidence of courses and there are 82 similar answers.

- CR1-2. Does not take notes. With an $80 \%$ coincidence of the courses and 9 similar answers.

Forum 2. Negative impact of passive students in the learning context

Table 5 shows the main negative impact in the learning context where passive students are. The first column "Type" identifies the 
answer (a type and a relative number are associated), the second column "Answer" describes the answer (if it is generic, more details are given in the table), the third column "Repetition" indicates the number of times that the answer has been said in the messages and the last column "Courses" the number of courses where that answer has been given. Remember the meaning of answers' types: AT- Attitude. PA- Proposed activities. LKLearning / Knowledge. CR-Attitude in the classroom

Table 5. Classification of answers in Forum 2

\begin{tabular}{|c|c|c|c|}
\hline Type & Answer (Student ...) & Repetition & Courses \\
\hline AT2-1 & $\begin{array}{l}\text {.. lacks of interest, } \\
\text { motivation and } \\
\text { involvement. }\end{array}$ & 29 & 4 \\
\hline AT2-2 & $\begin{array}{l}\text {... does not create positive } \\
\text { synergies }\end{array}$ & 5 & 3 \\
\hline PA2-1 & ... does not work in a team & 6 & 3 \\
\hline LK2-1 & $\begin{array}{l}\text {... does not acquire high } \\
\text { cognitive abilities }\end{array}$ & 34 & 5 \\
\hline LK2-2 & $\begin{array}{l}\text {... does not need } \\
\text { reinforcement }\end{array}$ & 18 & 5 \\
\hline CR2-1 & $\begin{array}{l}\ldots \text { is influencial on the } \\
\text { active students }\end{array}$ & 14 & 5 \\
\hline CR2-2 & $\begin{array}{l}\text {... doesn't understand } \\
\text { anything }\end{array}$ & 6 & 5 \\
\hline
\end{tabular}

\section{Attitude}

- $\quad$ AT2-1. Lack of interest in the subject. Namely, students is not being neither involved nor motivated. There is a coincidence of $80 \%$ of courses and 29 similar answers.

- $\quad$ AT2-2. Students does not create positive synergies. With a $60 \%$ match and 6 similar answers.

\section{Proposed activities}

- PA2-1. Student does not work in a feam, creates discomfort when he/she does it and not fulfilling his/her responsibilities. There is a coincidence of $60 \%$ of the courses and 6 similar answers.

\section{Learning / Knowledge}

- LK2-1. Students does not acquire high cognitive abilities. Therefore, his/her knowledge is volatile (not deep) and does not develop creativity, relationship, synthesis, expression, cooperation, etc. There is a $100 \%$ coincidence of courses with 34 similar answers.

- LK2-2. Student needs reinforcement for learning. This implies that teacher must work longer than planned. The specific difficulty is derived from the need for customization in resources, as well as the training plan. There is a $100 \%$ match and 18 similar answers are provided.
- $\quad$ CR2-1. Student infects other more active roommate. There is a $100 \%$ coincidence of courses and 14 similar answers have been provided.

- $\quad$ CR2-2. Student will not understand anything about the subject. There is a $100 \%$ coincidence of courses and 6 similar answers.

\section{Forum 3. Measurable indicators of learning improvement after applying innovation}

Table 6 shows indicators to show the learning improvement; namely, the impact of the applied educational innovation. The first column "Type" identifies the answer (a type and a relative number are associated), the second column "Answer" describes the answer (if it is generic, more details are given in the table), the third column "Repetition" indicates the number of times that the answer has been mentioned in the messages and the last column "Courses" the number of courses where that response has been given. Remember the meaning of answers' types: AT- Attitude. PA- Proposed activities. LK- Learning / Knowledge. CR- Attitude in the classroom. TA-Tutorial action.

Tabla 6. Classification of the answers in Forum 3

\begin{tabular}{|l|l|l|l|}
\hline Type & Answer (Students...) & Repetition & Courses \\
\hline AT3-1 & $\begin{array}{l}\text {...increases interest, } \\
\text { motivation, useful } \\
\text { vision, satisfaction }\end{array}$ & 43 & 4 \\
\hline PA3-1 & $\begin{array}{l}\ldots \text { shows greater } \\
\text { involvement }\end{array}$ & 42 & 5 \\
\hline PA3-2 & $\begin{array}{l}\ldots \text { creates } \\
\text { knowledge and } \\
\text { shares it }\end{array}$ & 12 & 4 \\
\hline LK3-1 & $\begin{array}{l}\ldots \text { improves } \\
\text { performance }\end{array}$ & 34 & 4 \\
\hline LK3-2 & $\begin{array}{l}\ldots \text { increases the own } \\
\text { learning autonomy }\end{array}$ & 6 & 4 \\
\hline CR3-1 & $\begin{array}{l}\ldots \text { increases } \\
\text { participation }\end{array}$ & 70 & 5 \\
\hline CR3-2 & $\begin{array}{l}\ldots \text { increases class } \\
\text { attendance }\end{array}$ & 17 & 3 \\
\hline TA3-1 & $\begin{array}{l}\ldots \text { increases tutoring } \\
\text { attendance }\end{array}$ & 9 & \\
\hline
\end{tabular}

These indicators are usually related to what is provided in the previous forums and are very useful for measuring the impact of educational innovation in a qualitative or quantitative way.

Attitude

- AT3-1. Emotional indicators such as: perception of utility, interest, satisfaction and positive attitude. There is a coincidence of $80 \%$ of courses and there are 43 similar answers. 


\section{Proposed activities}

- PA3-1. Greater participation and involvement in the proposed works: students carry the necessary material, participate in the cooperative work, prepare the issues, have carried out the previous activities, do not delay delivery, etc. $100 \%$ match of courses and 49 similar answers.

- $\quad$ PA3-2. Creation and sharing of knowledge. Students are able to generate learning resources, examples and in general new knowledge. They also share that knowledge. Matching $80 \%$ courses and 12 similar answers.

Learning / Knowledge

- LK3-1. Improvement of academic performance. With the same effort of learning than before applying innovation, there are more students who pass the subject and more cognitive level in learning. $80 \%$ of courses agree and there are 34 similar answers.

- LK3-2. Increased learning autonomy. $80 \%$ of courses agree and there are 6 similar answers.

Attitude in the classroom

- CR3-1. Increment of class participation. Increasing participation in debates, the number of questions asked in classroom. There is a $100 \%$ coincidence of courses with 70 similar answers.

- $\quad$ CR3-2. Greater class attendance without being mandatory. Matching $80 \%$ of courses with 17 similar answers.

Tutorial action

- TA3-1. Higher number of volunteer tutorial attendances than before applying the innovation.

\section{Conclusions}

Teachers usally only want to know if an innovation has worked or not in their own subject. However, in innovation in general, it must be contrasted globally or at least sectorally. common indicators must be taken, to allow measuring the impact of innovation both in the local environment where the innovation was applied and globally.

In this work it has been proven that among university teachers there is a common vision with respect to the root problem of the passive students. They agree on the characteristics of passive students, the impact on that target audience (negative impact in the learning context) and the indicators that would allow us to state that an concret innovation has worked in a specific sector (indicators of the impact of innovation to achieve active student habits). Those agreements are proved in the different forums and the fast convergence of unique indicators (table 3).

Regarding the characteristics of passive students; the indicators can be categorized into two groups: the observable ones without the intervention of students and those that can be observed before a demand for intervention required by the faculty (for example, participation in a debate). The characteristics of the first group are obtained directly from the attitude in classroom, through non-verbal language. The characteristcs of the second group are obtained from the zero reaction of students to any demand made by teachers, if it is easy (answer if you have understood something or not, ask questions, answer questions "thrown into class", go to the board), or if ir is a little more complex; for example, to carry out a proposed activity.

With respect to the impact of the passive students in the context of the subject, teachers mention three types of consequency depending to whom it affects: own student, teaching staff and whole teaching group. The negative emotional ones affect the own students (demotivation, disinterest, noninvolvement, etc.), as well as those that affect their training (no acquisition of high cognitive abilities), to teachers (teaching requires extra effort and it is often very difficult to perform, such as the support to the student who misses the subject rhythm and to the student who carries it well, at the same time) and the rest of their classmates (creating negative synergies and not working in the team).

Regarding the indicators that can measure the impact, they can be grouped into three groups: emotional and performance (both affect the individual) and participatory. In the last case, the teachers indicate that emotions are allied with the individual to increase interest in the subject, motivation, applicability, etc. With respect to the performance, students are not only able to get a better grade, but to take advantage of the resources, skills and abilities of the subject. The last group of indicators refers to active participation, by answering questions from both teachers and other students, by creating knowledge and by sharing it, by doing cooperative work, etc. In the end, by creating an active climate within the subject.

This work is a first approach to the search for common indicators to allow sharing experiences of innovation among teachers of any educational context. The following steps are focused on investigating more in the area of knowledge, the subject, the course and the educational level (degree, master, doctoral, etc.)

\section{ACKNOWLEDGMENTS}

This work has been partially funded by the Spanish Government Ministry of Economy and Competitiveness throughout the DEFINES project (Ref. TIN2016-80172-R) and the Educational Innovation Service of the Technical University of Madrid (Project IE1819.0602). The authors would like to thank the research groups GIDTIC (http://gidtic.com), GRIAL (http://grial.usal.es) and LITI (http://www.liti.es) for their support.

\section{REFERENCES}

[1] Ausubel, D.P. 1969. A cognitive theory of school learning. Psychology in the Schools. 6, 4 (Oct. 1969), 331-335. DOI:https://doi.org/10.1002/15206807(196910)6:4<331::AID-PITS2310060402>3.0.CO;2-W.

[2] Bloom, B.S., Engelhart, M.D., Furst, E.J., Hill, W. k. and Krathwohl, D. 1956. Taxonomy of educational objectives: The classification of educational goals. Handbook I: Cognitive domain. Taxonomy of educational objectives: The classification of educational goals. Handbook I: . David McKay Company. 201-207.

[3] Bonwell, C.C. and Eison, J.A. 1991. Active learning : creating excitement in the classroom. School of Education and Human Development, George Washington University.

[4] David, B.G. and Marshall, J.A. 2018. Epistemological tension in projectbased learning: Fabricated and propagated knowledge through practical and formal lenses. International fournal of Engineering Education. (2018). 
Dewey, J. 1916. Democracy and education; an introduction to the philosophy of education: The Macmillan Company.

[6] Dewey, J. 1929. Experience And Nature. George Allen \& UNWIN, LTD.

[7] Fidalgo-Blanco, A., Martinez-Nuñez, M., Borrás-Gene, O. and SanchezMedina, J.J. 2017. Micro flip teaching - An innovative model to promote the active involvement of students. Computers in Human Behavior. 72 , (2017). DOI:https://doi.org/10.1016/j.chb.2016.07.060.

[8] Fidalgo-Blanco, Á. and Sein-Echaluce Lacleta, M. 2018. ¿Qué hay que hacer para que una innovación educativa se consolide? Pedagogías emergentes : 14 preguntas para el debate. A. Fores Miravalles and E. Subias Valeccillo, eds. Ediciones Octaedro. 203.

[9] Fidalgo-Blanco, Á. and Sein-Echaluce, M.L. 2018. Método MAIN para planificar, aplicar y divulgar la innovación educativa. Education in the Knowledge Society (EKS). 19, 2 (Jul. 2018), 83-101. DOI:https://doi.org/10.14201/eks201819283101.

[10] Fidalgo-Blanco, A., Sein-Echaluce, M.L. and García-Peñalvo, F.J. 2016. Integration of the methods CBL and CBI for their application in the management of cooperative academic resources. 2016 International Symposium on Computers in Education, SIIE 2016: Learning Analytics Technologies (2016).

[11] Fidalgo-Blanco, Á., Sein-Echaluce, M.L. and García-Peñalvo, F.J. 2018. MAIN: Method for Applying Innovation in educatioN. Proceedings of the Sixth International Conference on Technological Ecosystems for Enhancing Multiculturality - TEEM'18 (New York, New York, USA, 2018), 806-813.

[12] Fidalgo-Blanco, Á., Sein-Echaluce, M.L. and García-Peñalvo, F.J. 2018. Micro Flip Teaching with Collective Intelligence. Learning and Collaboration Technologies. LCT 2018. Lecture Notes in Computer Science. I.A. Zaphiris P., ed. Springer, Cham. 400-415.

[13] Fidalgo-Blanco, A Sein-Echaluce, M.L., José, F. and Peñalvo, G. 2015 Identifying educational innovation characteristics. ACM International Conference Proceeding Series (2015).

[14] Fonseca, D., Martí, N., Redondo, E., Navarro, I. and Sánchez, A. 2014 Relationship between student profile, tool use, participation, and academic performance with the use of Augmented Reality technology for visualized architecture models. Computers in Human Behavior. 31, (Feb. 2014), 434-445. DOI:https://doi.org/10.1016/J.CHB.2013.03.006.

[15] Garcia-Peñalvo, F.J., Alarco, H. and Dominguez, A. 2019. Active Learning Experiences in Engineering Education. International fournal of
Engineering Education. 35, $1 \quad$ (2019), 305-309. DOI:https://doi.org/10.1119/perc.2015.pr.063.

[16] Honey, P. and Mumford, A. 1982. The Manual of Learning Styles: Peter Honey: 9780950844473. Peter Honey Publications.

[17] Johnson, D.W. and Johnson, R.T. 1979. Conflict in the classroom: controversy and learning. Review of Educational Research. 49(1), (1979), 51-70.

[18] Kolb, D.A. 1984. Experiential learning: Experience as the source of learning and development. Prentice-Hall, Inc.

[19] Lerís, D. and Sein-Echaluce, M.L. 2011. La personalización del aprendizaje: un objetivo del paradigma educativo centrado en el aprendizaje. Arbor. 187, Extra_3 (Dec. 2011), 123-134.

[20] Llorens-Largo, F., Gallego-Duran, F.J., Villagra-Arnedo, C.J., CompanRosique, P., Satorre-Cuerda, R. and Molina-Carmona, R. 2016 Gamification of the Learning Process: Lessons Learned. Revista Iberoamericana de Tecnologias del Aprendizaje. 11, 4 (Nov. 2016), 227-234. DOI:https://doi.org/10.1109/RITA.2016.2619138.

[21] Ochoa Cervantes, A.D. la C. and Pérez Galván, L.M. 2019. El aprendizaje servicio, una estrategia para impulsar la participación y mejorar la convivencia escolar. Psicoperspectivas. Individuo y Sociedad. 18, 1 (Mar 2019). DOI:https://doi.org/10.5027/psicoperspectivas-Vol18-Issue1fulltext-1478.

[22] Piaget, J. 1964. Part I: Cognitive development in children: Piaget development and learning. Journal of Research in Science Teaching. (1964). DOI:https://doi.org/10.1002/tea.3660020306.

[23] Sein-Echaluce, M.L., Fidalgo-Blanco, Á. and Alves, G. 2017. Technology behaviors in education innovation. Computers in Human Behavior. 72 (2017), 596-598. DOI:https://doi.org/10.1016/j.chb.2016.11.049.

[24] Sein-Echaluce, M.L., Fidalgo-Blanco, A. and García-Peñalvo, F.J. 2019 Technological ecosystems and ontologies for an educational model based on Web 3.0. Universal Access in the Information Society. (2019).

[25] Vygotsky, L. 1978. Interaction between learning and development. Mind

[26] 2015. Standards and Guidelines for Quality Assurance in the European
2019-1978) Higher Education Area (ESG). EURASHE. 